\title{
ІННОВАЦІЙНІ ЕЛЕМЕНТИ ДИДАКТИКИ В ПРОЦЕСІ НАВЧАННЯ ЛІКАРІВ-ІНТЕРНІВ ЗІ СПЕЦІАЛЬНОСТІ “УРОЛОГІЯ”
}

P. Р. Антонів

ДВНЗ “Івано-Франківський національниймедичнийуніверситет”

\section{INNOVATIVE ELEMENTS OF DIDACTICS IN THE COURSE OF TRAINING DOCTORS-INTERNS FOR A SPECIALTY "UROLOGY"}

R. R.Antoniv

\section{SHEI "Ivano-Frankivsk National Medical University"}

\begin{abstract}
Сучасні вимоги підготовки фахівців вимагають удосконалення навчального процесу на етапі інтернатури. Підвищити рівень підготовки лікарів-інтернів допомагають сучасні інформаційні та телекомунікаційні методики. Інтеграція сучасних технологій у навчальний процес є складовою частиною дидактики.
\end{abstract}

Modern requirements for preparation of experts demand improvement of educational process at an internship stage. Modern information and telecommunication techniques help to increase the level of preparation of doctors-interns. Integration of modern technologies into the educational process is a integral part of didactics.

Вступ. Найзначиміша проблема для системи освіти майбутнього - інтеграція, створення єдиного освітнього й інформаційного простору - прямо пов’язана з пріоритетами у сфері дидактики. При такому баченні перспектив розвитку освіти виявляється недостатнім орієнтуватися лише на необхідність передачі попередньо накопиченого досвіду, як це було раніше. Важливим $є$ уміння самостійно здобувати знання, уміти працювати з інформацією, аналізувати iii, бачити й вирішувати проблеми, що виникають у різних сферах діяльності [1].

Ми живемо в епоху високих комп'ютерних технологій та у світі електронної культури. Сучасна система медичної освіти починає переформатовуватися на створення методик, які орієнтовані на розвиток особистості тих, хто навчається. Інтерактивні освітні технології є тією сполучною ланкою, яка об'єднує новітні підходи до навчання зі стандартними класичними методиками. Нова якість сучасної освіти визначається не лише сліпим накопиченням знань, умінь і навичок, але й здатністю їх самостійно синтезувати, осмислювати та реалізовувати у професійну діяльність, що є основою самовдосконалення спеціаліста [2].

Іншим моментом $€$ те, що інтерактивне навчання спонукає до здорової конкуренції в пізнавальній, лі-

() Р. Р. Антонів кувальній, творчо-пошуковій діяльності, водночас уможливлює розв'язання проблемних питань у роботі з пацієнтами.

Основна частина. На різних етапах навчання лікаря використання інноваційних технологій $\epsilon$ найбільш доцільним в інтернатурі. У той час як навчання студентів-медиків вимагає здобуття глибоких первинних теоретичних знань, метою навчання лікарів в інтернатурі $€$ трансформація набутої теоріїу високопрофесійні фахові навики. Інтернатура сприяє зростанню здатності до самостійного прийняття необхідних рішень і формуванню вміння критично оцінювати результат своєї діяльності. Відповідно, і педагогічна технологія під час навчання лікарів-інтернів спрямована на максимальне отримання, перетворення та засвоєння інформації в короткий термін.

Типова навчальна програма інтернатури зі спеціальності "Урологія" передбачає 17 місяців (2652 навчальні години) навчання. 3 них 9 місяців (1404 навчальні години) навчання на кафедрі (очна частина), де переважна кількість часу відводиться таким формам навчання, як практичні заняття, семінари, конференції, а також самостійній роботі. 8 місяців (1248 навчальних годин) виділено для підготовки лікарівінтернів на базах стажування (заочна частина).

На жаль, на всіх етапах підготовки не завжди $\epsilon$ можливість наочно продемонструвати практичні на- 
вички, до яких належать специфічні маніпуляції, операції та тематичні пацієнти, що є недоліком навчання в інтернатурі, особливо в сучасних умовах розвитку медичних технологій та науки. Особливо це стосується таких поширених у всьому світі методик діагностики та лікування урологічної патології, як ендоскопія, ретроперитонео- та лапароскопія, роботизована хірургія. Для отримання та адекватного засвоєння такої професійної інформації плакатів та роз'яснень “на пальцях" вже недостатньо. В умовах глобального розвитку передових технологій мультимедіа - відеоігри, 3D-фільми - на сьогодні поставлена висока планка наочності. Як показує практика, можна досягти більш ефективних результатів, якщо інтерни будуть зацікавлені в процесі навчання. В зв'язку з цим, розширення можливостей викладання та засвоєння навчального матеріалу ми вбачаємо у введенні до навчальної програми практики перегляду трансляцій реальних операцій, відеоконференцій відповідно до тематики за допомогою контенту мережі Інтернет. Це дає можливість оптимізувати та засвоїти тематику, що винесена на самостійне опрацювання, а також організувати та виправити певні недоліки отримання практичних навичок під час проведення практичних та семінарських занять.

Кібернетичний простір містить величезний дидактичний потенціал, однак, для ефективного використання мережевих ресурсів у навчальних цілях, викладач повинен виступати в ролі фасилітатора (англ. facilitate - полегшувати), тобто людини, яка сприяє процесу правильного сприйняття отриманої інформації. Також важливим моментом є контроль та фільтрування матеріалів, які використовуються, наприклад з популярного сервісу відеохостингу YouTube. Проблемою даної форми навчання є, як відомо, велика кількість інформаційного “сміття”. Тому безконтрольний перегляд на початках отримання нової інформації може сформувати хибне уявлення про методики лікування. Основне завдання полягає в тому, що студент повинен отримати новітню світову інформацію у “чистому” вигляді. В даному контексті викладачу відводиться ще й роль модератора, завданням якого є забезпечення автентичності, фаховості отриманих з Інтернету методик. Спільний перегляд обраних матеріалів дає можливість коментувати побачене, акцентувати увагу на важливих деталях, при необхідності зупиняти, повторювати відео та проводити дискусію.

На сьогодні існує велика кількість спеціалізованих сайтів, де можна отримати фахову інформацію. Для перегляду відео з методиками сучасних операцій рекомендуються матеріали таких Інтернет-ресурсів, як WeвSurg, Uro.tv. Поглибити теоретичні знання дають можливість такі сайти, як Медстандарт.net, Uroweb.org, auanet.org, де можна знайти загальноприйняті на даний час основні матеріали з різних урологічних захворювань. Додатковим аспектом підготовки лікарів-інтернів, який особливо актуальний на етапах заочного навчання, є курси дистанційного навчання. Найбільш доступним навчальним ресурсом з урології є Uroedu. В зв’ язку з цим, перспективним моментом розвитку дидактики післядипломної освіти є впровадження дистанційної форми навчання на всіх навчальних базах післядипломної освіти вищих медичних навчальних закладів III-IV рівня акредитації з можливістю онлайн-доступу до них [3].

Ще одним позитивним моментом у навчанні майбутніх спеціалістів, який спрощує їх комунікацію 3 лікарським товариством, є доступність онлайн-зв' язку. Це дає можливість підвищувати свій рівень за рахунок участі в професійних онлайн-конференціях, майстер-класах, симпозіумах, з'їдах, які відбуваються по всьому світу. Інтерн самостійно наживо може брати участь у наукових дискусіях, що є частиною професійної освіти лікаря. Таким чином стимулюється професійний інтерес та розширюється професійний світогляд.

Окремим елементом в навчанні лікарів-інтернів $€$ можливість здійснення відеодзвінків та відеоконференцій між ними та їх керівниками на базах заочного циклу. Таким чином, користуючись можливостями мережі, лікарі-інтерни мають змогу удосконалювати та поглиблювати свої знання, отримуючи консультаційний супровід від кафедральних наставників. У свою чергу, для базової кафедри підвищується якість аудиту за вивченням, реферуванням та систематизацією матеріалу інтернами, що передбачено типовою навчальною програмою заочної частини інтернатури.

Таким чином, інтегрування новітніх комп'ютерних технологій у навчальний процес є частиною його дидактичної моделі та вимогою сьогодення [4]. Вони створюють умови для “. ... реалізації принципу особистісної зорієнтованості навчально-виховного процесу..., що на практиці означає підпорядкування основних заходів і засобів навчально-виховного процесу творенню й самотворенню особистості, розкриттю всіх потенційних можливостей індивіда та сприянню їх розвитку аж до осягнення найвищих ступенів" [5].

Висновок. Використовуючи новітні комп'ютерні технології та інтегруючи їх у навчальний процес, можна більш ефективно вирішувати цілий ряд дидактич- 
них задач у навчанні лікарів-інтернів: збільшити доступ до професійної інформації та розширити ії об'єм; закріпити здобуті теоретичні знання; сформувати та удосконалити теорію практичних маніпуляцій та опе-

\section{Література}

1. Дубасенюк О. А. Інноваційні навчальні технологіїоснова модернізації університетської освіти / О. А. Дубасенюк // Освітні інноваційні технології у процесі викладання навчальних дисциплін : зб. наук.-метод. праць / за ред. О. А. Дубасенюк. - Житомир : Вид-во ЖДУ, 2004.-- С. 3-14.

2. Рожко М. М. Методичні засади організації навчання лікарів-інтернів / М. М. Рожко, А. М. Ерстенюк, Н. В. Чаплинська // Медична освіта. - 2012. - № 3 (додаток). C. $146-148$.

3. Дистанційні технології навчання як одна з інноваційних технологій у навчальному процесі / I. В. Геруш, рацій; підвищити мотивацію навчання. Комунікативні технології дають можливість повною мірою реалізувати основні сучасні цілі вищої освіти.

В. А. Гайдуков, Ю. С. Букатару, І. М. Маринчина // Медична освіта. -2012. - № 3 (додаток). - С. 35-36.

4. Інноваційні технології і компетентнісний підхід у викладанні хірургії в аспекті кредитно-модульної системи організації навчального процесу / В. І. Лупальцов, Р. С. Ворощук, А. І. Ягнюк, І. А. Дехтярук // Медична освіта. -2012. - № 3 (додаток). - С. 98-101.

5. Боришевський М. Самовизначення і самореалізація особистості / М. Боришевський // Педагогічна газета. 2004. -№ 11.-C. 4.

Отримано 12.05.14 